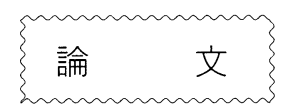

\title{
カキの浄化に及ぼす次亜塩素酸殺菌海水の影響について
}

\author{
井上典子* ·角田光淳* ·菅原龍幸** \\ $(*$ 杉並区衛生試験所 $\cdot * *$ 女子栄養大学)
}

\section{Effect of Hypochlorous Acid on Oyster based on Dehydrogenase Activity}

Noriko Inoue*, Koujun Tsunoda* and Tatsuyuki Sugahara**

*Suginami City Institute of Public Health, 3-20-3 , Takaidohigashi, Suginami-ku, Tokyo, 168-0072

**Kagawa Nutrition University, 3-9-21, Chiyoda, Sakado-shi, Saitama, 350-0288

$$
\begin{array}{cl}
* \text { \% } 168-0072 & \text { 東京都杉並区高井戸東 3-20-3 } \\
* * \boldsymbol{\top} 350-0288 & \text { 埼玉県坂戸市千代田 3-9-21 }
\end{array}
$$

Oysters have to be cleaned using sterilized seawater so that they may be eaten raw. We studied the effect of adding hypochlorous acid ( $\mathrm{HClO})$ to sterilize the seawater on oysters. Oysters with shells and without shells were prepared. Half of them were kept in seawater containing $2 \sim 3 \mu \mathrm{g} / \mathrm{ml}$ of $\mathrm{Cl}_{2}$, while the other half was kept in seawater without $\mathrm{HClO}$ as the control.All changes were observed and the dehydrogenase activity on the oyster's gills for 5 days (with shells) and for 48 hours (without shells) was measured.

In the seawater containing $\mathrm{HClO}$, the gills of oysters with shells became loose after 3 days. Oysters without shells looked smaller due to the $\mathrm{HClO}$ after 24 hours. The dehydrogenase activity of the oysters in contact with the $\mathrm{HClO}$, both with shells and without shells, decresased $70 \sim 90 \%$ compared to the control.

Although the oysters were not killed by the $2 \sim 3 \mu \mathrm{g} / \mathrm{ml}$ remaining $\mathrm{Cl}_{2}$, their gills were damaged. Since the gill's breathing helps oysters to be clean, the effect of clean up is thought to be reduced by the treatment.

\section{1. 緒言}

古代日本人の食生活にカキは重要な蛋白源であった。

「貝塚」からは必ずといっていいぼカキの殼が出土す るが，蛋白源の選択枝が広がった現在も，殼つき換算で 毎年20万トンを超えるカキが養殖されている1). その多 くはフライ, 鍋のよらに調理して食されるが, レモン酢, ポン酢などによる生食も好まれる。

日本の食生活における生食用魚介類の衛生確保につい ては, 古来からの経験則のみならず, 科学的な解析も加 えられている2 6).
生食するカキの衛生確保のために食品衛生法は, 細菌 数 $50,000 / \mathrm{g}$ 以下, E. coli 最確数 $230 / 100 \mathrm{~g}$ 以下と成分 規格を定めている．そのため，成分規格に合致するよう に「浄化」が行われている. 力キは海水温が $15{ }^{\circ} \mathrm{C}$ 前後の とき, 約 $10 l / \mathrm{hr}$ の海水をえらでろ過して吸水し， 6 時 間注どで約 $85 \%$ の内容物を消化する。「浄化」はこの性 質を利用して殺菌海水に入れて行われる ${ }^{7)}$. 用いられる 海水は紫外線殺菌海水, オゾン殺菌海水のほかに, 高価 でおおがかりな機器を必要としない次亜塩素酸で殺菌し た海水も用いられる。 また, 生食用力キの加工基準が, 浄化に際して次亚塩素酸ナトリウムの使用を認めている 
ことから，殺菌効果を期待してもき身カキのパック詰め のつけ水へ次亜塩素酸ナトリウムを添加することも見受 けられる。

次亜塩素酸は容易に細菌の細胞膜を浸透して酵素の働 きを止め殺菌作用を現す ${ }^{8)}$. フナには $0.5 \mu \mathrm{g} / \mathrm{ml}$ ，コイに は0.33 $2.0 \mu \mathrm{g} / \mathrm{ml}$ で致死させると言われている ${ }^{9)}$ が, ヘモシアニンを持つ貝類の呼吸活動に及添す影響につい ての報告は見当たらない。

今回, 次亜塩素酸がカキの浄化に関わるえらに及ぼす 影響について, えらの呼吸活動と密接な関係にある脱水 素酵素活性を著者らの報告 ${ }^{10)}$ によって試験し，あわせて 形態的变化を観察したので報告する.

\section{2. 実験方法}

\section{(1) 実験材料}

岩手県山田町産の殼つきカキを都内卸売市場から購入 した．実験ごとの実験材料は同一ロット品を用いた。

むき身の試験では，カキの外とら膜やえらなどを傷つ けないようにペンチで殼を少しずつ砕き，貝柱部分の殼 を残してむき身とした。

\section{(2) 試薬及び試液}

$2,3,5$-トリフェニルテトラゾリウムクロライド $\mathrm{T}$

$\mathrm{T} \mathrm{C}$ ) : 和光純薬工業 (株) 製

トリフェニルホルマザン ( T F ) : 関東化学 (株) 製 コハク酸ナトリウム（特級）：関東化学（株）製

塩化ナトリウム（日本薬局方）：大塚製薬（株）製 エタノール (特級) : 和光純薬工業 (株) 製

リン酸二ナトリウム（無水）（特級）：和光純薬工業 (株) 製

T T C 試液 ${ }^{10 ）}: 0.2 \% \mathrm{~T}$ T C $-0.1 \%$ ユハク酸ナトリウ ム $-2.84 \%$ リ酸二ナトリウム $-2.34 \%$ 塩化ナトリウム 溶液（p H9.2）

$\mathrm{T} \mathrm{F}$ 標準原液：エタノール $1 \mathrm{ml}$ 中に T F $1,000 \mu \mathrm{g} を$ 含むよらに調製した。

人工海水：ハイペット（株）製〈成分〉塩化ナト リウム, 塩化カリウム, 塩化マクネシウム, 塩化カルシ ウム, 硫酸マグネシウム, 硫酸マンガン等 他微量成分 次西塩素酸ナトリウム（食品添加物）：(株）オーヤラ ックス製＼cjkstart塩素濃度約 $6 \%$

(3) 装置

分光光度計：（株）島津製作所製 UV210A型 恒温水槽：トーマス科学 (株) 製 T-118型

(4) 脱水素酵素活性の測定

図1に示した。1 回のT F 測定にはカキ $4 \sim 8$ 個を供
し，平均值をとった.

Small pieces of gill $\quad 1 \mathrm{~g}$ TTC reagent $\left(0.2 \%\right.$ TTC $-0.1 \%$ sodium succinate ${ }^{-}$ $2.84 \%$ disodium hydrogen phosphate $-2.34 \%$ sodium chloride) $10 \mathrm{ml}$

incubate, $37^{\circ} \mathrm{C}, 30 \mathrm{~min}$

cool, quickly

take up the colored sample

ethanol $15 \mathrm{ml}$

stand $2 \mathrm{hrs}$, stirring occasionally, and extract $\mathrm{TF}$

filtor with filter paper

Filtrate

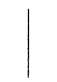

Colorimetry $(484 \mathrm{~nm})$

Fig. 1 Determination method of dehydrogenase activity in oyster's gill by colorimetry

Sample and TTC-reagent were previously kept below $5{ }^{\circ} \mathrm{C}$.

\section{（5）次亜塩素酸との接触方法}

殼つきのままのものと，開殼しむき身にしたものにつ いて別々に試験した.

初期值測定分を取り分けたカキを，人工海水を張った 水槽(殼つきカキ場合は $30 \ell$ 容のプラスチックコンテナ, むき身の場合は， 5 しのステンレスバット）に入れ，空 気を通じながら海水温 $8 \sim 12{ }^{\circ} \mathrm{C}$ で放置した. エアレーシ ョンは鑑賞魚用の小泡発泡器から通気した. はじめに, $1 \%$ 次亜塩素酸ナトリウムで残留塩素濃度を $2 \sim 3 \mu \mathrm{g}$ $/ \mathrm{ml}$ に調整した後, 水槽上部に $0.1 \%$ 次亜塩素酸ナトリ ウム人工海水溶液を満たした分液ロートをセットし, 残 留塩素濃度が $2 \sim 3 \mu \mathrm{g} / \mathrm{ml}$ 保つように滴下速度を調 整した. 残留塩素濃度はオルトトリジン法によって確認 した。

経時的にカキを 4 〜個ずつ取り出し脱水素酵素活性 を測定した. 同時に形態学的な観察を行った. 一方，対 照としては次亜塩素酸ナトリウム溶液を滴下しない人工 海水中のカキの脱水素酵素活性を測定した.

殼つきカキは 5 日間 ( 6 日目まで), さき身カキは48時 間後まで試験した。 


\section{3. 結果及び考察}

\section{(1) 殼つきカキ}

殼つきカキの脱水素酵素活性の経日変化を図 2 亿示し た．次亜塩素酸ナトリウムと接触させなかったカキの脱 水素酵素活性はほとんど変化せず，6日目の脱水素酵素 活性は初期值の約 $95 \%$ 以上であった。これは, 殼つきカ キが完全な個体であることに加光て, 人工海水, 空気の 補給等, 生活の条件が整っていたためと推察された。た だし，栄養分はミネラルだけで，有機質の栄養分が不足 していたことが微減の原因のひとつとも思われた。

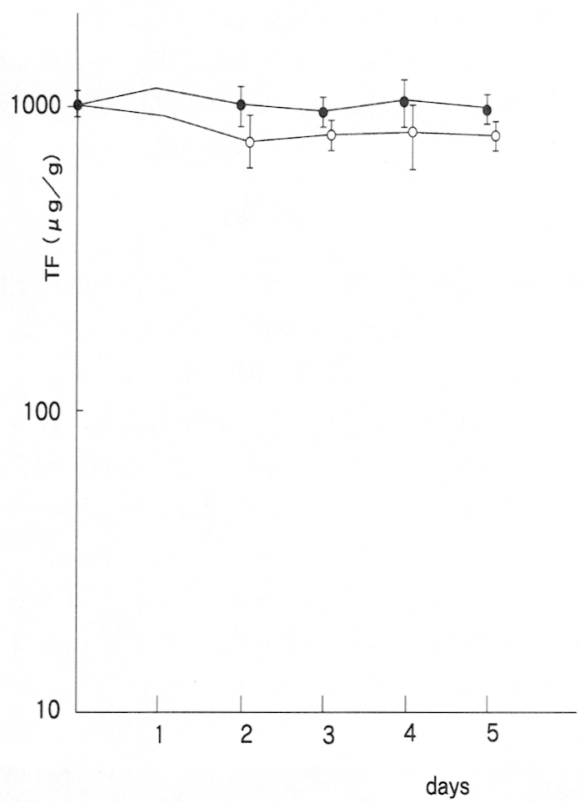

Fig. 2 Time course of dehydrogenase activity in oyyster's gill with $\mathrm{NaClO}$ 《With shells》

: control $\mathrm{O}$ : kept oyster in contact with $\mathrm{NaClO}$

一方, 次亜塩素酸ナトリウムと接触させたカキの脱水 素酵素活性は低下した. 2 日目に初期值の約 8 割 (81\%) となった後は活ぼ横ばいの活性度を示し，6日目には約 $78 \%$ であった. 最初に影響を受けた後, 対照のカキと同 様に約 2 割の低下で活性を保ち続けているのは, 生体の ホメオスターシスによる次曲塩素酸の分解, 排除が行わ れていることが考えられた.

次覀塩素酸ナトリウムと接触させたカキの殸の内液は 塩素臭はせず，オルトトリジン法によっても残留塩素は 検出されなかった，殼の状態は，対照は写真1のように 開いているのに対し，次西塩素酸ナトリウムと接触させ

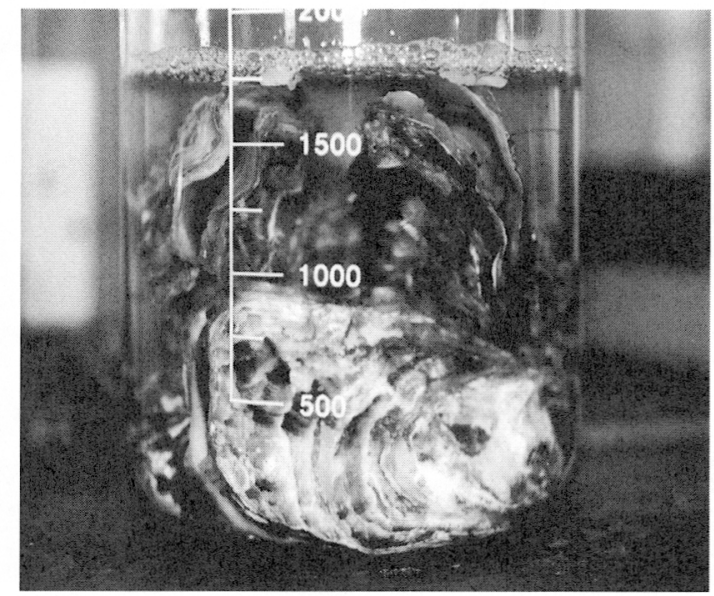

Picture 1 Ecological observation of oyster 《With shells. Control》

たカキは固く閉じていた、外部との接触を物理的に断ち， えらによる呼吸を低下あるい:停止させて海水を直接体 内に取り込むことを抑えている様子が同われた．力キの 殼の内液から塩素を検出しないことは, 殼の内部で次亜 塩素酸の分解が行われていることが推察された。えらの 状態を観察すると，3日目まではしっかりと正常な状態 を保っていたが，4 日目から次第に張りがなくなりピン セットでつまんだとき崩れやすくなっていた。

カキを入れた人工海水は換水せずに使ったが, 次曲塩 素酸ナトリウム接触の有無にかかわらず 6 日目まで濁ら ず澄んだままであった。

（2）むき身力キについて

むき身は, 殸つきに比べると環境の変化を直接に受け ることになる. 次亜塩素酸ナトリウム接触群, 対照群の どちらも, 殼つきカキでは見られなかった人工海水の污 れが観察された。これは外とう膜粘液によるものと思わ れ11)，その放出は殼内においては進入物への防御とも考 えられた，その污れは次亜塩素酸ナトリウムに接触させ た方が強く，10時間後に人工海水を換えた。対照は34時 間後に交換した.

むき身力キの脱水素酵素活性の経時変化を㘠 3 に示し た. 次㝳塩素酸ナトリウムに接触させなかったカキの脱 水素酵素活性は, 実験開始直後に急激に増加し, その後 やや減少しつつ平衡を保った。このことはさき身に特徵 的な挙動であった。

一方, 次亜塩素酸ナトリウムに接触させたカキの脱水 素酵素活性も対照と同じような「増加一微減」の経過を 示したが，その值は常に対照に比べて低く，李た経時に 


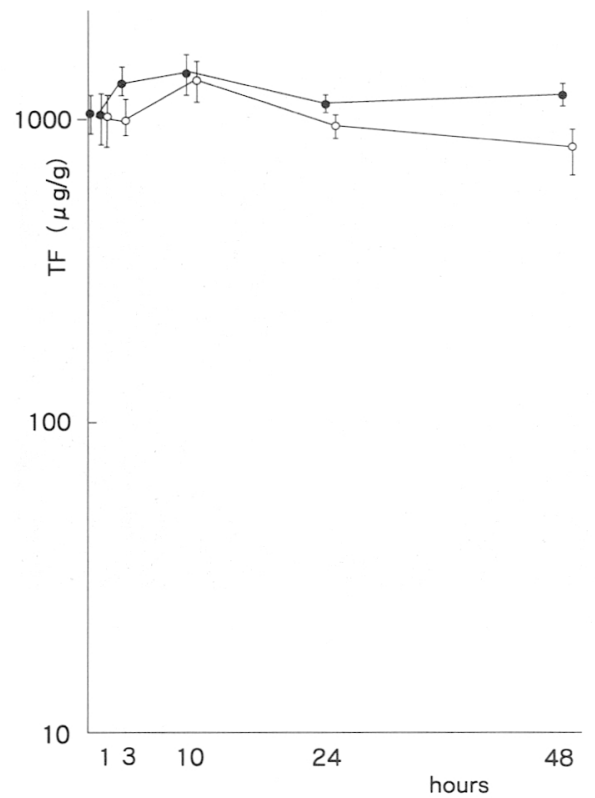

Fig. 3 Time course of dehydrogenase activity in oyster's gill with $\mathrm{NaClO}$ 《Without shells》

- : control $\bigcirc$ : kept oyster in contact with $\mathrm{NaClO}$

よる低下傾向は対照より大きかった４8時間後の脱水素 醉素活性は初期值の約 7 割であった。殼といら物理的な 防御機構がなく次曲塩素酸殺菌海水に個体全面が接触与 ることが，殼つきの場合より酵素活性が低下した原因で あると考えられた。导き身は，殼以外の機関はそろって

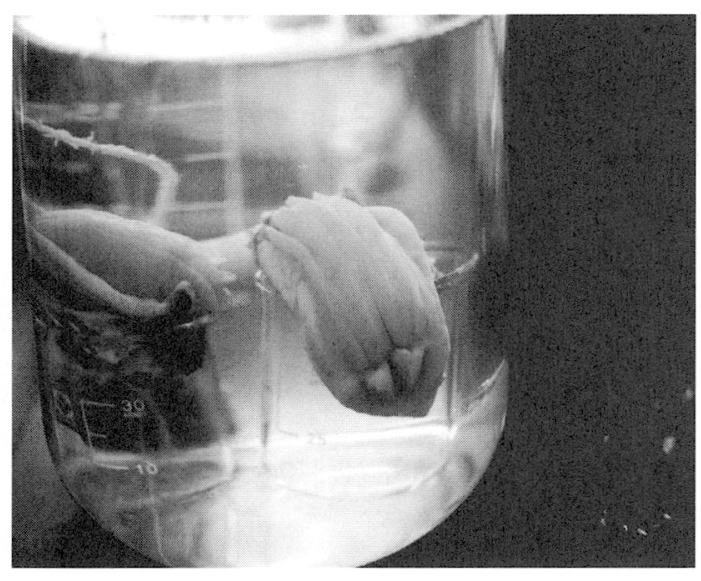

Picture 2 Ecological observation of oyster 《Without shells》

left : Control

right : kept oyster in contact with $\mathrm{NaClO}$ 
3) カキは残留塩素濃度 $2 \sim 3 \mu \mathrm{g} / \mathrm{ml}$ において致死 には到らなかったがえらをたたみ, 呼吸器系の活動は低 下し，生命維持には有害に動くものと思われた.

4 ）以上から, カキは殺菌料・次亜塩素酸ナトリウム に対して抵抗性はあるものの, 浄化がえらの呼吸活動に よることを考えあわせれば，力キの浄化効果は低下する ものと推測された. したがって, 次亜塩素酸殺菌海水を 用いる場合は, 殺菌後直ちに次亜塩素酸を含まない清浄 海水に入れ換えるか, 残留する塩素濃度を $0.2 \mu \mathrm{g} / \mathrm{ml}^{12}$ 以下の殺菌を目的とする最低限の低濃度に抑光て行ら必 要があると考えた。

\section{参考文献}

1）農林水産省統計情報部：ポケット農林水産統計一平成 11 年版一, 平成 11 年 3 月

2）厚生省環境衛生局監修“食品衛生検査指針（II）” P 204（1978）日本食品衛生協会

3）富山哲夫, 米 康夫, 井出克己：日本水産学会誌, 16, 538 (1950)

4）福田博業: 同上, 23, 486 (1957)

5）福田博業：同上，23，490（1957）

6）持永泰輔, 田口 昭：食品衛生学雑誌, 4, 217（1963）

7）佐藤忠勇：佐藤養殖場，的矢養蠇研究所資料（1982）

8）（株）オーヤラックス 作成資料p.2（1979）

9）好井久雄, 金子安之, 山口和夫：食品微生物学, 技報 堂, p. 400 (1971)

10）角田光淳，井上典子，青山光雄，長谷部昭久：食品衛 生学雑誌，27，487（1986）

11）小林新二郎：日本水産学会誌，30,893（1964）

12）水道法施行規則：厚生省令第 45 号，昭和 32 年 12 月 14 日 